\title{
シングルポイントダイヤモンド旋削による 光学ガラスの延性モ一ド切削加工に関する研究*
}

\author{
小倉 一 朗** 岡 崎袏 -** \\ Ductile-Regime Machining of Optical Glasses by Means of Single Point Diamond Turning
}

Ichiro OGURA and Yuichi OKAZAKI

This study presents experimental results on machining of optical glasses by using ultra-precision lathe. Four machining types, which are subdivision of ductile and brittle modes, are defined for a minute description of experimental results. The machining experiment for BK7 was tested in several atmospheres. Damage-free cutting mark can be obtained within 1-micrometer tool infeed in methanol and ethanol atmosphere. An evidence for about 0.5 micrometer spring-back in BK7 was obtained from microscopic observation and experimental data. Results of the cutting several materials are presented and discussed. Comparing maximum depth of groove in the ductile mode and the critical depth of tool indentation calculated from previous theoretical analysis, it was revealed that nearly same amounts of depth are confirmed in $\mathrm{SiC}$ and vitreous silica, but that in $\mathrm{BK} 7$ is different from theoretical one in a figure.

Key words: ductile-regime machining, brittle material, glass, single point diamond, fast tool servo

\section{1. 緒喜}

非球面の基礎形状の上に微細表面形状パターンを持つ ような高機能光学素子を創成するためには, ぜい性材料 である光学ガラスの精密切削加工技術の確立が必要であ る.

ガラスやセラミックスなどのぜい性材料は，ある臨界 量以下に切込み哚さを保って加工を行うとクラックのな い延性モード加工が可能となることが知られており1) 3), 現在まで様々な研究が行われている.

例えば超精密切削試験機によるシングルポイントダイ ヤモンド切削に関しては，シリコンとゲルマニウムの臨 界切込み深さの評価 ${ }^{4}$ をはじめとして，BK7と低熱膨張ガ ラス(Zerodur)の切込み実験)およびF2ガラスに対する工具 すくい角の影響評価的が行われている。

また傾斜プランジカットによるシリコン，ゲルマニウ ムの切込み実験 ${ }^{7)}$, 円弧切削型試験機を用いた複数のガラ スに対する臨界切込み樑さの評価8)等がある。

さらに引っかき試験の研究に関しては, SEMチャンバ 内での各種ガラスに対する圧子侵入と引つかき実験の評 価 ${ }^{9)}$ や高静水圧下におけるシリコン, ガラスの臨界深さ に関する検証 ${ }^{10)}$ 等がある.

そして実験だけではなく, 分子動力学シミュレーショ ンによる計算機上での微細加工現象解明の試みもなされ

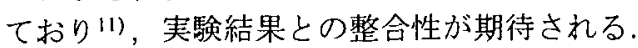

これらの研究はぜい性材料の微細切削現象の解明八向 けたきわめて有益な結果であり，実用的切削加工を行う ためにも，今後もさらに研究を進めてゆく必要がある。

ところが従来の研究で用いられてきた切削加工装置は， いずれも試験機としての性格が強く，実際の生産機械を 直接目指すものではなか力た。ぜい性材料の切削加工法 を確立し，生産技術のブレークスルーを図るためにも， 実用機をべースとした加工ジテムによって加工条件を

* 原稿受付 平成11年11月18日

** 正会員 機械技術研究所（つくば市並木1-2)
考慮した材料加工の微細メカニズムを解明する必要があ る。

一方，加工対象に関して，光学素子の創成を目標とす るならば，現在広く光学素子として用いられているBK7 についての切削, 研削実験が重要となってくるが, その データがいまだそしいという指摘がある ${ }^{12)}$.

ところで従来の研究における切込み深さに関する主要 な検討対象は, 臨界切込み深さの值に限られ, 切込み深 さと得られる切削痕深さの詳細な関係はあまり視野に入 れられていないようである.

もっとも，加工装置等のコンプライアンスにより，工 具送り量と実切込み深さが異なる゙ため, 実切込み深さ 検出を行わない以上，切込两媣さと切削痕深さの関係の 評洒は不可能である。しかし運動転写原理によるぜい性 材料の加工技術を実用化するという観点においては，工 具送り量をそのシステムにおける切込み深さととらえ, 切削痕深さとの関係を評価することには意義があると考 えられる。

以上にもとづき本研究では，より実用に近い高速工具 サーボ搭載超精密旋盤によるぜい性材料の延性モード切 削加工技術の確立を目的とする. そしてその基礎研究と して，光学ガラスを中とした各種ぜい性材料に対する 切込み実験を行い, 延性モードからぜい性モードへの遷 移現象を調べる。

本報では延性，ぜい性加工モードをさらに細分化した4 種の加工タ.イプの定義を行う。そして各種雲囲気下，各 種試料に対して，工具切込み深さを変化させていったと きの加工痕を観察し, 定義した加工タイプと工具切込み 深さおよび切削痕深さの関係をまとめた結果について述 ベる.

\section{2. 実 験 の概 要}

\section{1 高速工具サーボ搭载超精密旋盤}

図1に本研究で用いた実験装置の概要を示す。これは シングルポイントダイヤモンド旋削を行うための高速工 具サーボ搭載超精密旋盤である ${ }^{13)}$. 
高速工具サーボは圧電アクチュエータによって約 $2 \mathrm{kHz}$ の応答帯域, 約 $2 \mathrm{~nm}$ の分解能で工具切込み深さを制御で きる．高速工具サーボ先端に取り付けられているダイヤ モンドバイトはノーズ半径 $0.2 \mathrm{~mm}$, 寸くい角 $0^{\circ}$ のもので ある。

実験中の主軸回転速度は90rpmで一定とした。主軸に 取り付けられた $\phi 60 \mathrm{~mm}$ 用の真空チャックで試料を固定す る. 取り付けにともなう面傾斜については, 試料が 1 回 転するうちに3回の切込みを与え, その切削痕を確認した 結果, ほぼ等しい長さであったため問題はないとした。

\section{2 加エタイプの分類}

ぜい性材料の加工における延性とぜい性の2つの加工モ 一ドは, 切削痕におけるクラックなどの欠陥の有無を観 察することによって判断される.

本研究では実験結果をより細かく把握するため, この 2 つの加工モードをさらに細分化した。図2 はBK7の切削 痕をノマルスキー型微分干渉顕微鏡で観察したものであ る.これは1本の加工痕に沿って切込み深さを増加させた ときの遷移の状況を示す．これより，以下の 4 つの加工タ イプを定義した。

【タイプ1】切削痕の幅が狭く, 切削痕の深さも小さいも の.クラックは発生しておらず, 切削痕の両側に盛り上 がりが見られる。

【タイプ2】タイプ1に対して切削痕の幅が急に広がるが, クラックはタイプ1同様存在しないもの. 延性モードによ る加工であり，このタイプの加工を持続することによっ てぜい性材料のクラックフリーの加工が可能となる.

【タイプ3】加工痕内部に進行方向直角に細かいき裂が生 じているもの，加工痕の外側にも斜め前方に細かいき裂 が確認されるが，材料の脱落は見られない.

【タイプ4】切削痕全面にわたって一様な材料の破砕・脱 落が見られるもの，全面的なぜい性モードによる加工．

図2(b)のタイプ2の遷移に関して興味深い結果が見られ る.この図は左上から右下へ向かって切込み梁さが増加 して切削が進んでおり, 図の中央やや右下あたりでタイ プ1からタイプ2へ，そしてすぐにタイプ3に遷移している.
この実験中ダイヤモンドバイト先端の摩耗により, 刃先 が二又に分かれたような工具で切削を進めていったため, ガラス表面には2本の切削痕が刻まれている。タイプ2の 切削に移行しているのは左側の筋であるが，右側の筋は タイプ1のまま特に影響を受けていない.これは切削条件 が何らかの臨界点を越えると急激にタイプ1から2への遷 移現象が生じることを示唆するものである.

\section{3 実験手順}

実験は以下のような手順で行った。

今回の実験で用いた加工試料はBK7, SiC, 溶融石英ガ ラスの 3 種類である. 試料を主軸に取り付け, 旋盤主軸が 1 回転する間に 3 回切込みを与えた. 切込み形状は主軸回 転に応じて切込み深さが線形増加するのこぎり波状で, 工具の送り量は $4 \mu \mathrm{m}$ に設定した. 図3に得られる切削痕 を模式的に示す.このときの切込み開始点は工具サーボ と試料の初期位置によって決まる.

加工中は旋盤の $x$ 軸を固定し, 試料の一定半径位置を切 込んだ. 切込みを与える半径を10〜25mm としたため, 半 径の大きさによって切削速度が異なる. しかし最大, 最 小半径で切込みを行った切削痕を観察すると, 加工夕イ プの遷移はほぼ同一の回転角度で生じていた，そのため 本研究ではこの程度の切削速度の違いによる影響は無視 できるものとした.

切込みを行う直前に各種の試薬を加工点にかけ，加工 雲囲気を変更した。今回設定した䨌囲気は, ドライ, 水, ヘプタン, オクタン, メタノール, エタノール, プロパ ノールである. 一つの雾囲気に対して切込み半径を変え た実験を3回行った。

切込み実験後, 試料を回転ステージにのせ, 切削痕の 状態をノマルスキー型微分干涉顥微鏡で観察した。その 際, 各加工タイプの遷移点を回転ステージの角度目盛で 記録した．顕微鏡で確認された切削の開始点を工具刃先 の最初の切込み点とし, そこからの回転角度と指令信号 から工具切込み深さを定めた。

ところでこの工具切込み深さには先にも述べたように 装置のコンプライアンスの問題による試料の逃げの分

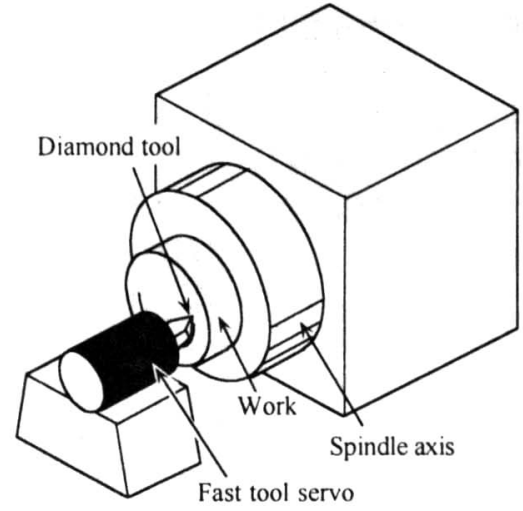

Fig. 1 Ultra-precision lathe with fast tool servo

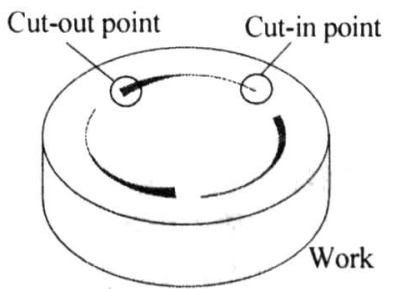

Fig. 3 Scheme of cutting marks

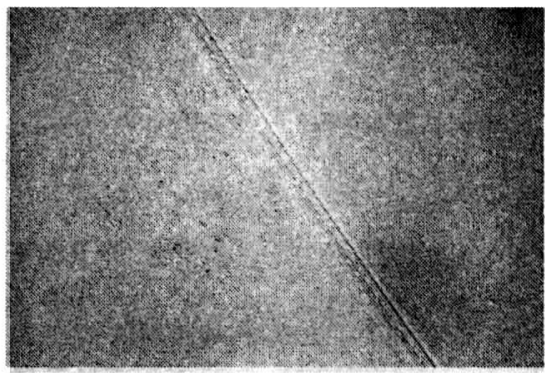

(a) Type-1

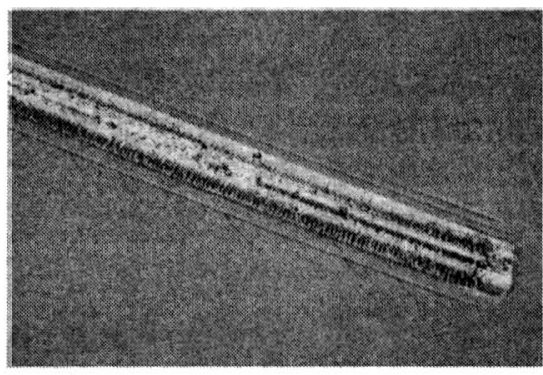

(c) Type-3

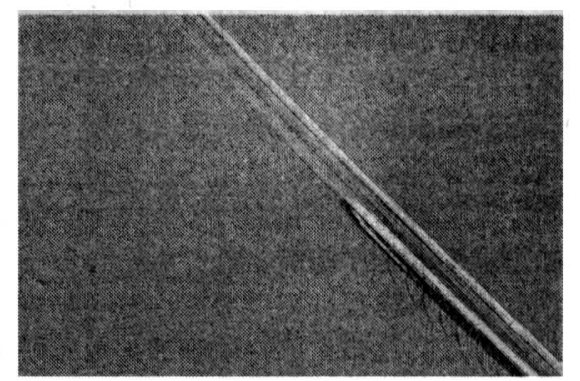

(b) Type-2

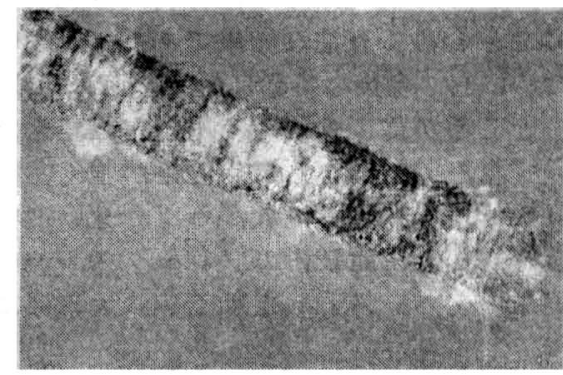

(d) Type-4

Fig. 2 Machining types of cutting brittle material 


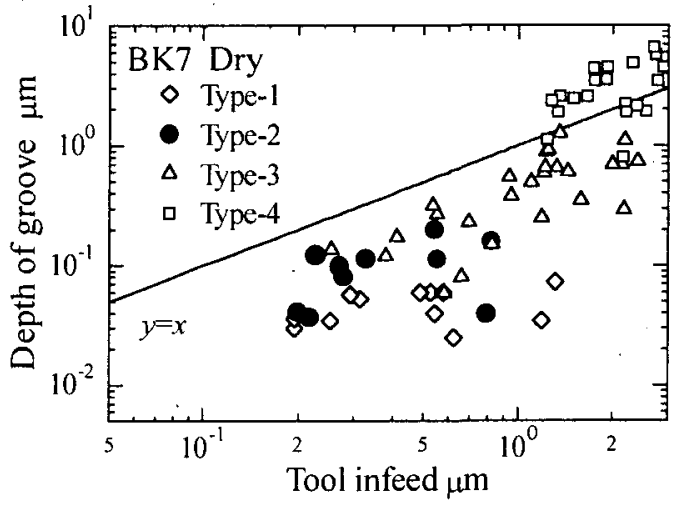

(a)

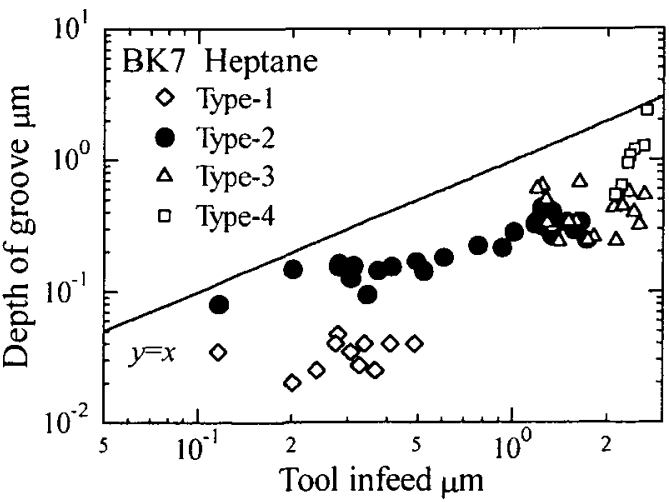

(b)

Fig.4 Results of cutting experiment

が含まれている，そのためこれを試料に対する真の切込み 梁さであるということはできない。この量は実際には試料 や装置全体を含めた系からみた工具刃先の送り量に相当す る. しかし本研究ではこれをあえて本システムにおける切 込み深さとして以下の議論を進める. 正確な切込み深さを 求めるためには試料面の逃げ量を測定寸る必要があるもの の, 測定システムの構築などの困難さがある. そのためこ の問題は次の機会に譲ることにする.

続いて触針式粗さ計 (Rank Taylor Hobson 社製 TalyScan) を用いて切削痕媣さを観察した. 粗さ計の触針先端半径は $5 \mu \mathrm{m}$, 最小分解能は $3 \mathrm{~nm}$ である. 顕微鏡観察時に記録し たステージの回転角を用いることにより，工具切込み深さ に応じてどのような加エタイプが出現し，そのときの切削 痕深さはどうなっているかを関連づけることができる。

以上の実験を上にあげた各種の雲囲気，試料について行 い, 各加工条件が加工結果に与える影響を調べた.

\section{3. 実 験 結 果}

\section{1 加工带囲気の影策}

図4に切削実験結果の一例を示す。これは試料をBK7，加 工雲囲気を(a)はドライ，(b)はヘプタンとしたものである. これらの結果は, 半径別に3回切削実験することで得られ た条痕についてまとめたものである:これらの各点で観察 された加工タイプを種類別にプロットしている.

このグラフにおいて $x$ 軸は，工具刃先と試料表面の接触 点からの工具切込み指令信号によって定めた切込み染さで ある. また $y$ 軸は, 粗さ計で測定した切削痕深さである.

グラフ中の直線は $y=x$ であり, この直線上の点は工具切 込み深さと切削痕媣さが一致していることを意味寸る。(a), (b)共にタイプ4に至るまでプロットされた点は $y=x$ の下側 にある。これは各切込み染さに対して得られた切削痕の深 さが常に小さいことを示す，その原因は工具先端から工具 サーボ, 旋盤, チャック，試料へいたる装置のコンプライ アンスによるものと考えられる。

図4 (a)，(b)に掠ける加工条件の違いは加工䨌囲気のみで あるが，その結果には際立った相違がみられる。

まず(a)の雾囲気ドライの場合, 工具が試料に接触して から切込み深さ $1 \mu \mathrm{m}$ までの間において, 同一の切込み深 さであってもタイプイ 3が混在して発生しており, 各加工 タイプの発生には関連性が見られない. またその切削痕深 さにもばらつきが大きい。

これに対して(b)の雲囲気へプタンの場合は, 各タイプ
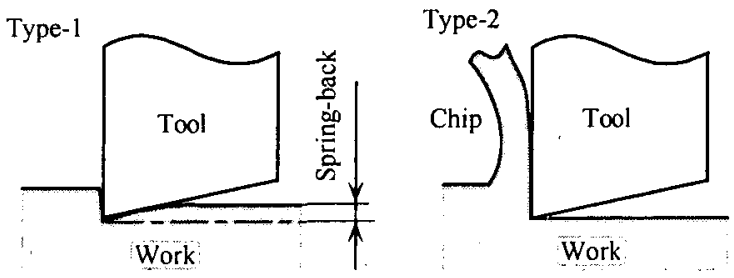

Fig.5 Cutting model for two machining types

の遷移が明りょうに確認できる.タイプ2が切込み媣さ $0.5 \sim 1.2 \mu \mathrm{m}$ の間で単独に得られており, その切削痕深 さと切込み深さにほぼ一対一の関連性が見られる。これ は延性モードの切削加工が安定に得られていることを意 味する。

タイプ1とタイプ2が切込み染さ（図中 $x$ 軸方向） 0.1 $0.5 \mu \mathrm{m}$ の間で混在しているが, 両者の切削痕深さ $(y$ 軸

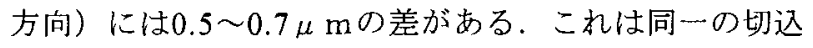
み染さに対して異なる加エタイプが出現していることを 示す。この結果は雾囲気を変えた場合においても確認さ れた。

これより, タイプは場合, 試料は工具の下に潜り込 んでから再び弾性回復をおこし，塑性変形の分だけが切 削痕として残るが，ある臨界点を越えると切りくずがす くい面に沿って流机出してタイプ2となる可能性が推察 できる.この様子を概念的に図5に示す。これは先の加 エタイプの分類において，タイプ1からタイプ2への遷移 を顕微鏡で観察したものに符合する.

各種雾囲気下で得ら礼た結果を図6にまとめて示寸. (a)は各切込み深さに対して発生した加エタイプの別を示 したもので，図4における $x$ 軸方向と加エタイプの関連性 をまとめたものに相当する，これは本システムでどの程 度の切込み深さで加工タイプが遷移するかを意味してい る.

図6(a)より次の結果が確認できる. ドライでは $0.2 \mu \mathrm{m}$ 以上の切込み哚さになると加工モードが混在して発生し, 安定な切削は望めない，加工雾囲気を水にした場合，夕 イプ2の加工痕が存在寸る切込み深さ自体は $1.5 \mu \mathrm{m}$ ほど の幅を持っているが，その籁囲では同時にタイプ1ある いはタイプ3が現れており，タイプ2は単独では得られな い.

これに対しへプタン,オクタン,メタノール，エタノ ールでは安定にタイプ2で切削できる切込み深さが存在 する. 特にメタノール, エタノールでは切込み深さ $0.2 〜$ $1.2 \mu \mathrm{m}$ 範囲にわたっており, 実用的にガラスを延性モ 
$\diamond$ Type-1 - Type-2 $\Delta$ Type-3 $\square$ Type-4

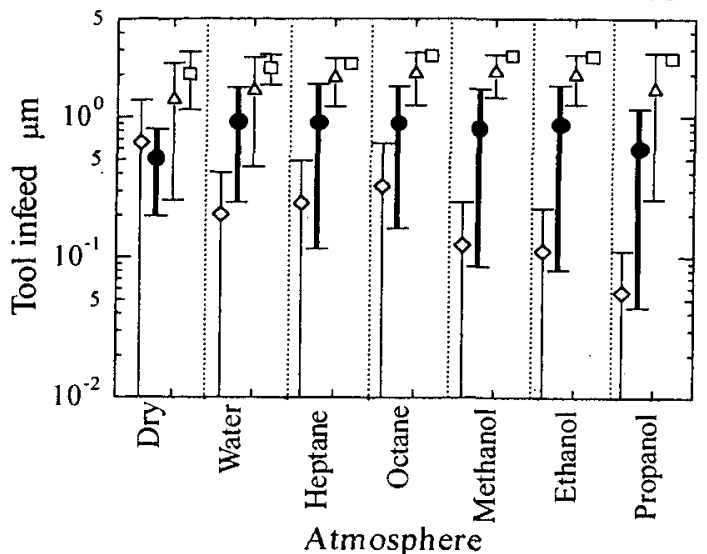

(a)

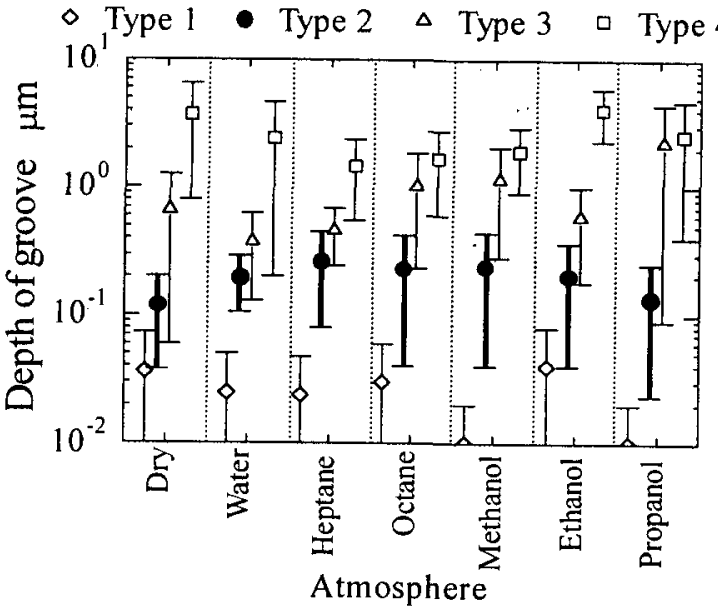

(b)

Fig.6 Machining types under various atmospheres

ードで切削加工する可能性が伺える。ところが雾囲気が 同じアルコール系のプロパノールになると，切込み深さ が0.25 $\mu \mathrm{m}$ 以上でタイプ3の切削が発生し，タイプ2のみが 得られる範囲がかえって狭まり安定な加工の継続には問 題がある。

図6(b)は得られた切削痕深さと加エタイプの別を示した もので，図4の $y$ 軸方向との関連性に相当する.

雲囲気がドライの場合，タイプ2の発生する切削痕の限 界の染さは0.2 $\mu \mathrm{m}$ までであったが，それ以外の雲囲気で は0.3 $\mu \mathrm{m}$ 以上までとなっている.またクラックの存在す るタイプ3を生じる切削痕深さについてむ，雾用気による 違いが認められる. ドライの場合, 切削痕深さが $0.06 \mu \mathrm{m}$ になるとタイプ3がすでに発生しているが，雾囲気が水， プロパノールでは約 $0.15 \mu \mathrm{m}$, ヘプタン, オクタン, メタ ノ一ル，エタノールの場合 $0.2 \mu \mathrm{m}$ の深さまでは欠陷が生 じていない.

以上により，加工雲囲気が試料表面に影響を及ぼし加 工の状況に変化を与えていることが確認できた。 そして 今回の実験結果の範囲では，試料BK7に拉いて，雾囲気义 タノール，エタノールでもっとも望ましい切削加工が行 われることがわかった。

\section{2 加工対象による遣い}

加工対象を変えた場合の加工結果の違いについて調べ た. 図7にその結果を示す。これは加工霖囲気を水として $\mathrm{BK} 7, \mathrm{SiC}$ ，溶融石英ガラスの各試料を切削したものであ る、これを見ると各試料の種類によってそれぞれ特徵的 な結果が得られていることがわかる。

まず，図7(a)のBK7については，先の実験で得られたよ うに切込み深さと切削痕深さに明確な関連性が見られる. タイプ1,3との混在があるものの，タイプ2の切削は切込 み深さ0.2〜 $1.5 \mu \mathrm{m}$ の間でそれにほぼ比例した深さの切削 痕が得られている.

次に試料をSiCにした場合，図7(b)に示すように切込み 深さを大きくしても切削痕深さが増大しない状況が確認 できる．タイプ2の切削痕の深さは $0.3 \mu \mathrm{m}$ 以上ものまで

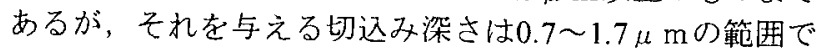
あり, BK7の半分程度しかない。 また同一の切込み深さに よって生ずるタイプ2の切削痕深さには大きなばらつきが 見られる。

図7(c)の試料が溶融石英ガラスの場合は，材料の破壊が

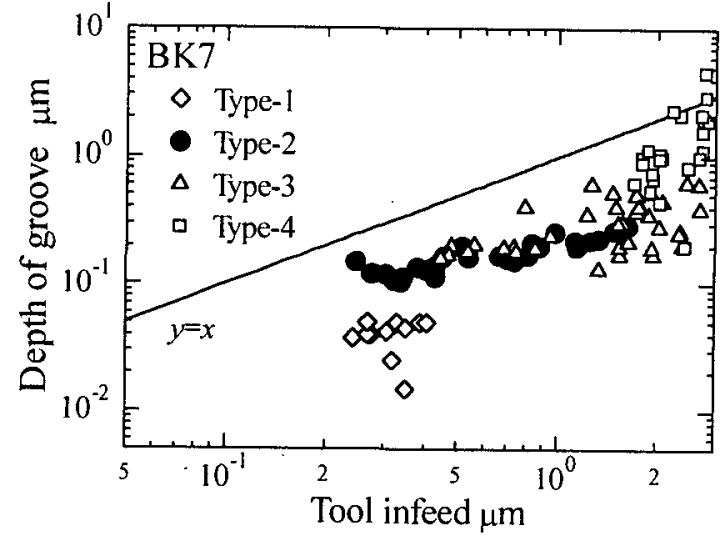

(a)

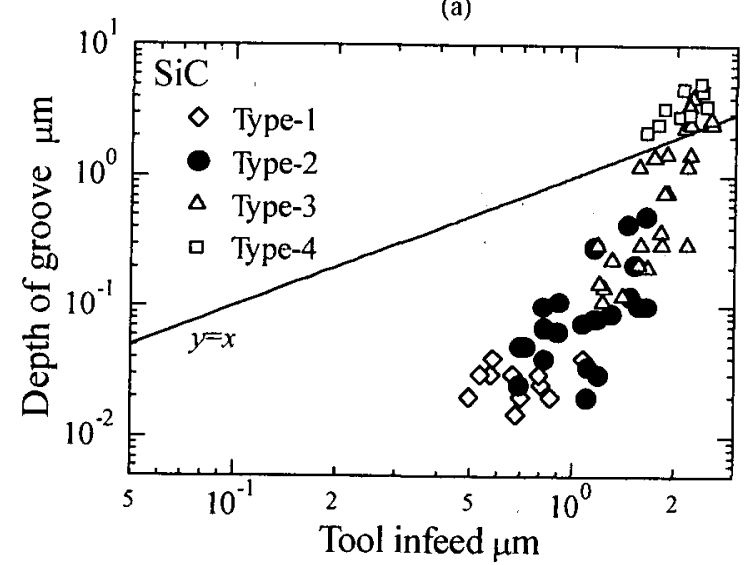

(b)

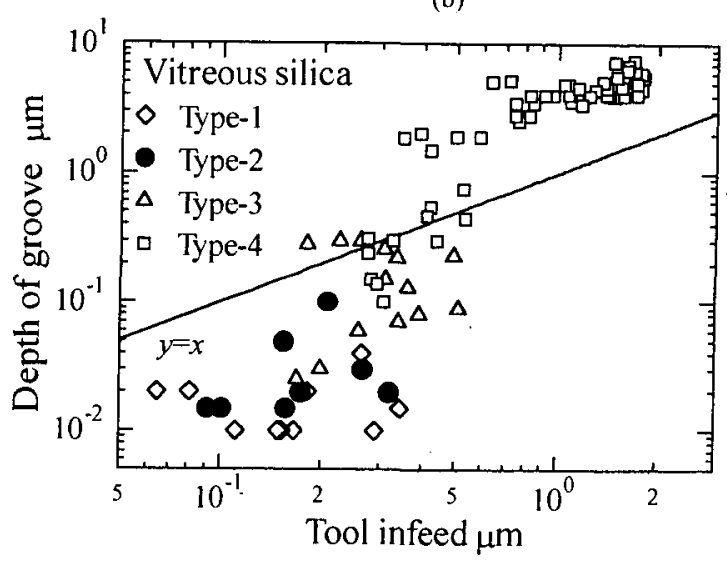

(c)

Fig.7 Experimental results of several materials 
Table 1 Characteristics of test materials and calculated $d$

\begin{tabular}{lll|c|c|c}
\hline \multicolumn{3}{c|}{ Materials } & BK7 & SiC & $\begin{array}{c}\text { Vitreous } \\
\text { silica }\end{array}$ \\
\hline Fracture toughness & $K_{K}$ & $\mathrm{MPa} \mathrm{m}^{1 / 2}$ & 0.2 & 4 & 0.75 \\
Young's modulus & $E$ & $\mathrm{GPa}$ & 81.5 & 420 & 70 \\
Hardness & $H_{V}$ & $\mathrm{GPa}$ & 5.1 & 24 & 6 \\
\hline Critical depth of cut & $d_{C}$ & $\mu \mathrm{m}$ & 0.025 & 0.49 & 0.18 \\
\hline
\end{tabular}

切込み深さの小さいときから始まっている様子がわかる． 得られた結果は大きくぜい性破壊しているタイプ4が主流 であり，タイプ1,2のクラックフリーの加工は切込み媣さ, 切削痕深さともごく小さい範囲でしか存在していない.

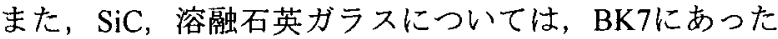
ようなタイプ1と2の染さについての不連続性があまりみ られなかった。

以上の結果から，上記 3 種類のぜい性材料の中ではBK7

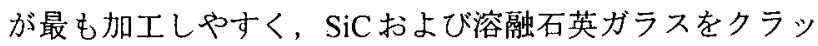
クフリーで加工することは困難であることがわかる。

この結果について以下の考察を加えてみた.

Griffithのき裂伝播の解析により，延性一ぜい性遷移臨 界押込み深さd $d_{c}$ は次の式で与えられる1).

$$
d_{c} \approx \frac{E}{H_{V}}\left(\frac{K_{\mu}}{H_{V}}\right)^{2}
$$

ただし

$E ;$ †ング率, $H_{V}$; ビッカース硬さ， $K_{K}$; 破壊じん性值で ある

表 1 に今回の実験で用いた各試料の破壊じん性値, ヤン グ率，ビッカース硬さおよびそれらの值から計算された 臨界深さを示す。

今，切削痕深さを真の切込み深さに対応寸るものと考 えると，SiCおよび溶融石英ガラスに関してはタイプ2の 切削痕深さの最大值は計算された $d_{c}$ に近いものとなって いる．一方でぜい性破䱋をおこしているタイプ3は 小さい值で生じている，しかしこのdc值は圧子押込みに関 するものであり，加工における臨界值はこれよりかなり 小さくなる。たとえば研削加工を行う場合の臨界切込み 深さは臨界押込み深さの15\%程度に見積もられているた め1)，本実験の結果は妥当性をもっていると思われる.

これに対してBK7の臨界押込み深さ $d_{c}$ は0.025 $\mu \mathrm{m}$ とか なり小さい，この值は図7(a)のタイプ1の切削痕深さにし か相当せず，タイプ 2 の最大の切削痕哚さが約 $0.2 \mu \mathrm{m}$ あることを見ると一けた異なる。

しかしながらすくい角 $-45^{\circ}$ ，切削速度 $20 \mathrm{~m} / \mathrm{s}$ の場合,

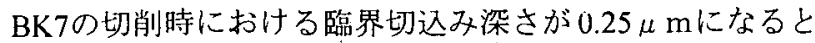
いう報告もなされている7)。本実験で得られた結果はこち らの值に近く，BK7の切削時における臨界切込み深さは 圧子押込みの場合に対し大きい值をとる可能性がある.

\section{4. 結譶}

ぜい性材料の運動転写原理による加工の実用化を目指 すため, 光学ガラスBK7および各種ぜい性材料を高速工具 サーボ搭載超精密旋盤によるシングルポイントダイヤモ ンド旋削の加工実験を行い，延性モードからぜい性モー ドへの遷移現象について調べた，本研究の内容をまとめ ると以下のようになる。
（1）ぜい性材料における延性，ぜい性モードの2つの 加エモードを切削痕の状態から4つの加工タイプに 細分化した。

（2）装置のコンプライアンスの影響により，タイプ4 になるまで切削痕媣さは常に切込み深さより小さ くなった。

（3）BK7を試料とした加工実験の結果，同一の切込 み深さであってもタイプ1と2では切削痕の媣さが 異なることを観察した。これはガラスの弾性回復 によるものと考えられる。

（4）各種の加工雲囲気下での切削加工実験を行った。 加工雰囲気をメタノール，エタノールにすると切 削痕深さで $0.2 \mu \mathrm{m}$ ，本システムによる切込み深さ で1.2 $\mu \mathrm{m}$ まで安定した加工が得られる.

（5）加工対象によって特徽の異なる加工結果を得た。 BK7は加工しやすいが，SiCおよび溶融石英ガラス でクラックフリーの加工を行うことは難しい. $\mathrm{SiC}$, 溶融石英ガラスの実験によって得られたタイプ2の 最大の切削痕深さは計算される臨界押込み哚さに 近いものとなったが，BK7については一けた大き い值を得た。

\section{哴辞}

本研究を遂行するにあたり，山梨県工業技術センター の西村通善氏，韓国 釜山大学校の林漢錫氏のご協力を得 ました。記して感謝いたします。

\section{参、考、文 献}

1) T. Bifano, T. Dow and R. Scattergood : Ductile Regime Grinding: A New Technology for Machining Brittle Matterials, ASME, J. Eng. Ind., 113, 5, (1991) 184 .

2) 宮下政和：ぜい性材料の延性亡ード研削加工技術一ナノ研 削技術への道, 精密工学会誌，56, 5, (1990) 782 .

3) 谷 泰弘: 延性モード加工, 生産研究, 43, 11, (1991) 472:

4) P. N. Blake and R. O. Scattergood : Ductile-Regime Machining of Germanium and Silicon, J.Am.Ceram.Soc., 73 ,4, (1990) 949.

5) P. A. McKeown, K. Carlisle, P. Shore and R. F. J. Read : Ultraprecision, High Stiffness CNC Grinding Machines for Ductile Mode Grinding of Brittle Materials, 精密工学会誌, 56, 5, (1990) 806.

6)山田収, 西口 隆, 桝田正美, 内田浩二: ガラスの臨界 切込み深さに及ぼす工具すくい角の影響，1990年度精密工 学会秋季大会学術講演会講演論文集, (1990) 751 .

7) E. Brinksmeier, W. Preu $\beta$ and $O$. Riemer : From Friction to Chip Removal. An Experimental Investigation of the Microcutting Process, Proc. 8th Intern. Prec. Eng. Seminar, (1995) 335.

8) M. G. Schinker : Subsurface Damage Machanisms at High-Speed Ductile Machining of Optical Glasses, Prec. Eng., 13, 3, (1991) 208.

9) 江田 弘, Lotfi Chouanine, 清水 淳: ガラス引っかき過程 の延性発現の検証一鋭利なダイヤモンド圧子を用いた場合 一, 精密工学会誌, 64, 4, (1998) 613.

10）吉野雅彦，青木隆幸，杉島泰介，白樫高洋：高静水圧環境 下における硬ぜい材料の引っかき加工試験，精密工学会誌， 65, 10, (1999) 1481.

11) 島田尚一, 田中宏明, 井川直哉：分子動力学による単結晶 シリコンの微小加工機棈の解明，1999年度精密工学会秋季 大会学術講演会講演論文集, (1999) 203.

12）江田 弘, 山本佳男, 秋山贵信, 石原浩輔 : セラミックス とガラスの多目的延性モード加工機械の開発, 精密工学会 誌, 62, 2, (1996) 236 .

13）岡崎祐一：ダイヤモンド旋削による微細表面形状の創成， 真空, 40, 6, (1997) 541 